\title{
Association of Academic Stress, Anxiety and Depression with Social-Demographic among Medical Students
}

\author{
Dube Adiele ${ }^{1}$, Chamisa Judith A ${ }^{2}$, Gundani P. Morgan ${ }^{1,3}$, Bako Catherine ${ }^{2}$, Lunga M. Carolyne ${ }^{4}$ \\ ${ }^{1}$ Department of Health Education, Southern Africa Nazarene University, Manzini, Swaziland \\ ${ }^{2}$ Division of Social Medical Sciences, National University of Science and Technology, Bulawayo, Zimbabwe \\ ${ }^{3}$ Department of Sports Science and Coaching, National University of Science and Technology, Bulawayo, Zimbabwe \\ ${ }^{4}$ Department of Journalism and Mass Communication, University of Swaziland, Kwaluseni, Swaziland \\ Correspondence: Dube Adiele, Department of Health Education, Southern Africa Nazarene University, Manzini, \\ Swaziland. E-mail: adieledube@yahoo.com
}

Received: March 12, 2018

doi:10.11114/ijsss.v6i6.3288

\author{
Accepted: April 5, $2018 \quad$ Available online: May 18, 2018 \\ URL: https://doi.org/10.11114/ijsss.v6i6.3288
}

\begin{abstract}
Background: Medical education programmes aim at producing wholesome of competent and skilled graduates, research have shown that students experience stress which impacts on their health, academic performance and social functioning. This paper aims to determine the extent of academic stress, depression and anxiety among medical undergraduates and to explore the correlation between academic stressors, psychological stress and socio-demographic background among first year medical students at National University of Science and Technology.

Method: This descriptive cross-sectional study was undertaken by first-year medical students in 2016 at NUST Division of Social Medical Sciences. A validated and standardised survey Depression Anxiety Stress Scale (DASS 42) questionnaire was used. Data was analysed by SPSS version 21.0.

Results: Nineteen first-year midwifery students participated in the study. Males were $63.1 \%$ while females were $38.8 \%$. Seventy-three per cent of the participants experienced stress during the programme, of which forty-nine percent were females. Female students showed severe stress of $6 \pm 1.15$ as compared to their male counterparts who scored extremely severe stress of $3.81 \pm 1.53$. Academic, health-related and psychosocial problems were the chief sources of stress.

Conclusion: Stress impacts negatively on undergraduate students. Midwifery students need guidance, mentorship and educational integration support to identify and monitor their own well-being. These measures should promote a balance in selection of positive strategies to overcome stress, managing workload and time effectively during study period.
\end{abstract}

Keywords: midwifery students, anxiety, depression, stress

\section{Introduction}

Medical education is perceived as one of the most stressful fields of study due to its challenging professional and academic requirements. In the $21^{\text {st }}$ century, several studies have been reported through systematically reviewed and published literature concerning high incidences of stress among medical students (Khosla and Chaudhuri 2017, Shah etal 2010, Waqas et al 2015, Dyrbye et al 2010, Bayram and Bilgel 2008, Dahlin et al 2005, Aktekin et al 2001, Bramness 1991, Chandavarkar et al 2007, Malathi and Damodaran 1999, Eller et al 2006, Niemi and Vainiomaki 1999). Transformation from insecure student to young knowledgeable physician results in medical students encountering numerous angst.

The chief objective of medical training programmes is to produce knowledgeable, skilful, competent and professional graduates who will render comprehensive healthcare services within their communities (Abraham et al 2009, Naidoo et al 2014, Sani et al 2014). Lectures, tutorials, experiential learning placements, apprenticeships (Naidoo et al 2014) and mentoring overloaded with facts are inevitable by students in most medical programmes, therefore spending many hours daily trying to achieve the expected academic outcomes. These among others are; extensive medical curricula, academic performance and frequent evaluations, fear of failure, vast amount of content that has to be mastered. Long working hours, 
inter-personal issues at the institution, high family and peers' expectations, financial issues and lack of leisure time are found to be the most constant sources of stress towards goal achievement (Shah etal 2010, Abraham et al 2009, Naidoo et al 2014, Soumya et al 2015, Sidik 2003).

Literature reveals that medical undergraduate students greatly undergo psychological distress which may lead to more suicidal ideation, to psychiatric disorders than the general population (Waqas et al 2015, Dyrbye et al 2010, Bayram and Bilgel 2008, Dahlin et al 2005, Aktekin et al 200, Sani et al 2014). Consequently they suffer from deteriorating academic performance, impairment in functioning, stress induced disorders and also negative effects of emotional distress causing impairment in functioning (Bayram and Bilgel 2008, Shriram et al 2015, Shawaz et al 2015, Sidik et al 2003, Khosla and Chaudhuri 2017). Therefore, this paper aims at: (1). determining the extent of academic stress, depression and anxiety among medical undergraduates (2). exploring the correlation between academic, psychological and socio-demographic background stressors among midwifery students at National University of Science and Technology (NUST).

\section{Methodology}

\subsection{Setting and Sample}

This cross-sectional descriptive study was conducted in the Medical Schools at National University of Science and Technology, Zimbabwe during September - November 2016. A total of 19 first year students (12 males and 7 females) were recruited. The sample comprised of students who hold a nursing diploma, various clinical practical as midwives and those with extensive clinical environment exposure. Only students who had enrolled for at least six months prior to study and present on the day of the survey were requested for participation.

\subsection{Ethical Considerations}

Study protocol was approved by the NUST ethical committee. All students who participated in the study were informed about the objectives of the study and an informed written consent was obtained from each participant. Trained research assistants were used to explain the instrument. The students were informed that participation in the study was voluntary and that they had the choice to remain anonymous.

\subsection{Data Collection Procedure}

A self-administered, pre-designed, pre-structured, pretested questionnaire which included a previously validated and standardised survey instrument; Depression Anxiety Stress Scale (DASS 42) was used to assess information on anxiety, depression, socio-demographic and stress. Collected data was on basic socio-demographic and personal characteristics.

\section{Data Analysis}

The data were analysed with SPSS Inc., (Chicago, Illinois, USA) version 21.0 software. Continuous data were expressed as mean \pm SD. Correlations between continuous variables were calculated using ANOVA. The $\chi^{2}$ test was used to determine the association of each factor with socio-demographic among the respondents. For the association between factor and socio-demographic student's t-test for independent samples were used, at a $P$-value of $<0.05$ was considered statistically significant.

\section{Results}

The response rate was $100 \%$. Males were $63.1 \%$ while females were $38.8 \%$. The mean ages for males and females were; $24.38 \pm 1.56$ years and $22.43 \pm 1.28$ years respectively. Most of the respondents were housed under rented accommodation $(84.2 \%), 10 \%$ in parental houses whilst only $5.3 \%$ resided in students' residence facilities.

Table 1 below showed that gender, marital status and academic pressure were statistically significant $(\mathrm{p}<0.05)$. Although the scores were higher among motivational influence to enrolling in the medical field, the difference was not significant. Social and financial obligations from a third party (parents/family, private contracts, loan or sponsor) was reported by sixteen participants $(84.2 \%)$. The majority of students $(36.8 \%)$ were expected to pay the borrowed finances back with an interest percentage to either banking institutions or private financial agencies. 
Table 1. The students' profile basing on socio-demographic characteristics $(n=19)$

\begin{tabular}{|c|c|c|c|}
\hline Variable & $\mathbf{N}$ & $\%$ & P-value \\
\hline $\begin{array}{ll}\text { Sex } & \text { Male } \\
& \text { Female }\end{array}$ & $\begin{array}{c}12 \\
7\end{array}$ & $\begin{array}{l}63.1 \\
38.8\end{array}$ & $0.01 *$ \\
\hline $\begin{array}{l}\text { Marital Status: } \begin{array}{l}\text { Single } \\
\text { Married }\end{array}\end{array}$ & $\begin{array}{c}8 \\
11\end{array}$ & $\begin{array}{l}42.1 \\
57.9\end{array}$ & $0.02^{*}$ \\
\hline $\begin{array}{l}\text { Living Accomm odation: Dormitory } \\
\text { Parental Home } \\
\text { Rented Accommodation }\end{array}$ & $\begin{array}{c}1 \\
2 \\
16\end{array}$ & $\begin{array}{c}5.3 \\
10.5 \\
84.2\end{array}$ & 0.12 \\
\hline $\begin{array}{l}\text { Motivation to enroll in medical field } \\
\text { Family influence } \\
\text { Personal interest } \\
\text { No choice }\end{array}$ & $\begin{array}{c}5 \\
12 \\
2\end{array}$ & $\begin{array}{l}26.3 \\
63.2 \\
10.5\end{array}$ & 0.36 \\
\hline $\begin{aligned} \text { Academic Pressure: } & \text { Yes } \\
& \text { No }\end{aligned}$ & $\begin{array}{c}18 \\
1\end{array}$ & $\begin{array}{c}94.7 \\
5.3\end{array}$ & $0.013 *$ \\
\hline $\begin{array}{l}\text { Social \& Financial Obligations: } \\
\qquad \begin{array}{l}\text { None } \\
\text { Parent/Family } \\
\text { Private contracts } \\
\text { Loans } \\
\text { Sponsor } \\
\text { No sponsor }\end{array}\end{array}$ & $\begin{array}{l}2 \\
3 \\
1 \\
7 \\
5 \\
1\end{array}$ & $\begin{array}{c}10.5 \\
15.8 \\
5.3 \\
36.8 \\
26.3 \\
5.3\end{array}$ & 0.287 \\
\hline
\end{tabular}

$$
\mathrm{p}<0.05
$$

Table 2 below shows that there was decreased DASS score percentage for subscales (Anxiety, Depression, Academic Stress) from mild, moderate and severe stress group in all students, which was statistically significant $(\mathrm{p}<0.05)$. The same finding was observed in male students but female students did not show much difference as the severity of stress increased. Female students showed severe stress of $6 \pm 1.15$ as compared to their male counterparts who scored extremely severe stress of $3.81 \pm 1.53$. The female students compared to male students were not statistically significant in severe and extremely severe stress percentage scores.

Table 2. DASS scores distribution of medical undergraduate students according to severity $(n=19)$

\begin{tabular}{|c|c|c|c|c|c|}
\hline \multicolumn{2}{|c|}{ DASS Score } & Mild & Moderate & Severe & Extrem ely severe \\
\hline Anxiety: & $\begin{array}{l}\text { Male } \\
\text { Female } \\
\text { Total }\end{array}$ & $\begin{array}{l}6.14 \pm 1.16 \\
5.61 \pm 1.08 \\
5.97 \pm 1.14\end{array}$ & $\begin{array}{l}5.21 \pm 1.73 \\
5.43 \pm 1.25 \\
5.36 \pm 1.37\end{array}$ & $\begin{array}{l}4.46 \pm 1.39 \\
5.61 \pm 1.35 \\
5.05 \pm 1.42\end{array}$ & $\begin{array}{l}3.14 \pm 1.64 \\
2.43 \pm 1.07 \\
2.89 \pm 1.53\end{array}$ \\
\hline Depression: & $\begin{array}{l}\text { Male } \\
\text { Female } \\
\text { Total }\end{array}$ & $\begin{array}{l}6.26 \pm 1.42 \\
5.81 \pm 1.49 \\
6.15 \pm 1.47\end{array}$ & $\begin{array}{l}5.36 \pm 1.71 \\
5.98 \pm 1.61 \\
5.67 \pm 1.31\end{array}$ & $\begin{array}{l}5.73 \pm 1.91 \\
5.73 \pm 1.23 \\
5.74 \pm 1.27\end{array}$ & $\begin{array}{l}3.28 \pm 1.43 \\
2.80 \pm 1.40 \\
3.16 \pm 1.42\end{array}$ \\
\hline Stress: & $\begin{array}{l}\text { Male } \\
\text { Female } \\
\text { Total }\end{array}$ & $\begin{array}{l}6.88 \pm 1.23 \\
6.76 \pm 1.19 \\
6.79 \pm 1.07\end{array}$ & $\begin{array}{l}5.99 \pm 1.19 \\
5.27 \pm 1.25 \\
5.76 \pm 1.07\end{array}$ & $\begin{array}{l}5.39 \pm 1.86 \\
6.43 \pm 1.15 \\
6.26 \pm 1.08\end{array}$ & $\begin{array}{l}3.81 \pm 1.53 \\
3.65 \pm 1.23 \\
3.73 \pm 1.03\end{array}$ \\
\hline
\end{tabular}


Table 3. Association or Anxiety, Depression, Stress with socio-demographic characteristics of participants

\begin{tabular}{|c|c|c|c|c|c|c|c|}
\hline Determinants & \multicolumn{2}{|l|}{ Categories } & Anxiety & Depression & Stress & Odds Ratio (OR) & $95 \%$ CI for OR \\
\hline Gender * & \multicolumn{2}{|l|}{$\begin{array}{l}\text { Male } \\
\text { Female }\end{array}$} & $\begin{array}{l}9.41 \pm 3.24 \\
6.53 \pm 2.36\end{array}$ & $\begin{array}{l}7.33 \pm 3.30 \\
9.17 \pm 2.46\end{array}$ & $\begin{array}{c}9.87 \pm 2.16^{*} \\
10.68 \pm 3.27^{*}\end{array}$ & $\begin{array}{c}1 \\
1.314\end{array}$ & $0.534-2.136$ \\
\hline Marital statıs* & \multicolumn{2}{|l|}{$\begin{array}{l}\text { Single } \\
\text { Married }\end{array}$} & $\begin{array}{c}8.00 \pm 2.26 \\
10.86 \pm 3.10\end{array}$ & $\begin{array}{c}8.00 \pm 8.26 \\
10.86 \pm 3.10\end{array}$ & $\begin{array}{c}8.00 \pm 2.26 \\
10.86 \pm 3.10\end{array}$ & 1.501 & $0.426-2.876$ \\
\hline Age & \multicolumn{2}{|l|}{ Continuous v ariable } & & & & 0.78 & $0.431-1.120$ \\
\hline Semester* & \multicolumn{2}{|l|}{$2^{\text {nd }}$} & $10.38 \pm 6.56$ & $12.32 \pm 7.91$ & $11.43 \pm 6.92$ & 0.163 & $0.018-0.679$ \\
\hline Psychosocial stressors*** & $\begin{array}{l}\text { (Loneliness } \\
\text { Family problems } \\
\text { Lack of entertainment } \\
\text { Inability to socialize with peers } \\
\text { Financial strain) }\end{array}$ & $\begin{array}{l}\text { Yes } \\
\text { No }\end{array}$ & $\begin{array}{c}9.43 \pm 5.12 \\
10.30 \pm 7.86\end{array}$ & $\begin{array}{c}8.59 \pm 4.35 \\
10.23 \pm 7.85\end{array}$ & $\begin{array}{c}10.91 \pm 7.65 \\
9.35 \pm 6.22\end{array}$ & 1.156 & $0.571-2.534$ \\
\hline Health-related stressors** & $\begin{array}{l}\text { (Difficulty sleeping } \\
\text { Class attendance } \\
\text { Quality of cafeteria food } \\
\text { Power failures) }\end{array}$ & $\begin{array}{l}\text { Yes } \\
\text { No }\end{array}$ & $\begin{array}{l}11.82 \pm 7.08 \\
10.50 \pm 7.61\end{array}$ & $\begin{array}{c}11.69 \pm 8.63 \\
9.14 \pm 7.25\end{array}$ & $\begin{array}{l}15.96 \pm 8.41 \\
13.43 \pm 8.48\end{array}$ & 0.567 & $0.247-1.518$ \\
\hline Academic stressors*k*k & $\begin{array}{l}\text { (Academic curriculum } \\
\text { Exam frequency } \\
\text { Academic performance } \\
\text { Lack of leisure time) }\end{array}$ & $\begin{array}{l}\text { Yes } \\
\text { No }\end{array}$ & $\begin{array}{l}11.45 \pm 6.89 \\
10.49 \pm 7.36\end{array}$ & $\begin{array}{c}12.03 \pm 7.34 \\
9.84 \pm 7.35\end{array}$ & $\begin{array}{c}12.34 \pm 6.14 \\
9.16 \pm 7.47\end{array}$ & 2.04 & $1.126-3.254$ \\
\hline
\end{tabular}

$* \chi^{2}=2.79, \mathrm{p}<0.005 \quad * * \chi^{2}=1.83, \mathrm{p}<0.05 \quad * * * \chi^{2}=6.49, \mathrm{p}<0.0001$

Table 3 shows the levels and intensity are shown for psychosocial stressors, health-related stressors and academic stressors. The different stressors were reported as follows; psychosocial stressors, health-related stressors ( $\mathrm{OR}=1.156$ and 0.567 respectively) and for academic stressors where $\mathrm{OR}=2.04$. Chi-square revealed a significant association between psychosocial, health-related stress and social demographic characteristics $\left(\chi^{2}=1.83, p<0.05\right)$, academic stress $\left(\chi^{2}=6.49\right.$, $\mathrm{p}<0.0001)$. Independent sample $\mathrm{T}$ test revealed a significant association in mean scores of DASS scale and socio-demographic characteristics. Students who reported psycho-social stress, health-related stress and academic stress as had a higher mean \pm sd on DASS scale than their counterparts who reported that they had no stress.

\section{Discussion}

In the present study the extent of academic stress, depression and anxiety among medical undergraduates evaluated and the correlation between academic stressors, psychological stress and socio-demographic background among these students was explored. Life of a Medical training school student is intended to prepare graduates for a personally rewarding and socially meaningful career (Shah et al 2010, Shawaz et al 2015, Hershner and Chervin 2014, Khosla and Chaudhuri 2017), despite that it can be very stressful. Due to academic stress together with high academic and professional expectations, recent researches have been reporting mild, moderate, and high levels of stress, burnout and even suicidal ideation during amongst medical students and health care professionals from other countries (Waqas et al 2015, Hershner and Chervin 2014).

In the present study, eighteen participants $(94.7 \%)$ indicated that they experienced stress at some point during their undergraduate medical studies. Female students perceived more stress levels than their male counterparts, however $\chi^{2}=$ 2.79 , showing statistical significance and association only in case of stress scores $(\mathrm{p}<0.005)$ compared to anxiety and depression scores. This is consistent with other previous studies reported higher scores of anxiety, depression and stress compared with their male counterparts (Eller et al 2006, Naidoo et al 2014, Shawaz et al 2015, Singh et al 2010, Supe 1998, Johari and Hassim 2009, Khosla and Chaudhuri 2017). Increased level of stress in female students may indicate a decrease of psychological health and easy articulation of depressive symptoms which may affect students' performance, reduced learning and eventually affect patient care (Sani et al 2012).

\section{Conclusion}

This current study revealed the levels and sources of stress among first-year undergraduate medical students. It also indicated that academic problems were the main sources of stress compared to non-academic problems. Females had comparatively more stress levels than their male counterparts. 


\section{Study Limitations}

Our study was limited to first-year midwifery undergraduate students only. Our study population comprised a small number of both male and female students, and therefore differs from those on other Zimbabwean medical schools. Therefore, the results of this study are specifically for those who are in part-time programme and cannot be generalised to other medical schools in the Southern Africa.

\section{Recommendations}

Once the quality and levels of stress are identified, counselling, coping strategies, stress reduction/management can be adapted to assist in preventing stress-related problems. Mentorship and educational support programmes should be integrated into the undergraduate midwifery curriculum and made available to all clinical students. Future research is prescribed to expand the extent of this report by tending to the adapting methodologies that are used by midwifery undergraduate students to manage clinical stress.

\section{Conflict of interest}

There is no conflict of interest.

\section{Acknowledgement}

Great appreciation is passed to the contribution of the bachelor of nursing science students and NUST Division of Social Medical Sciences in assisting in completion of study.

\section{References}

Abraham, R. R., Zulkifli, M. E., Fan, Z. S. E., Xin, N. G., \& Lim, G. T. J. (2009). A report on stress among first year students in an Indian medical school. South East Asian Journal of Medical Education, 3, 1023-1029

Ahmed, W., Spogmai, K., Waqar, S., Uzma, K., \& Asad, A. (2015). Association of academic stress with sleeping difficulties in medical students of a Pakistani medical school: a cross sectional survey. Peer J., 3, e840. https://doi.org/10.7717/peerj.840

Aktekin, M., Karaman, T., Senol, Y. Y., Erdem, S., Erengin, H., \& Akaydin, M. (2001). Anxiety, depression and stressful life events among medical students: a prospective study in Antalya, Turkey. Med Educ., 35, 12-17. https://doi.org/10.1046/j.1365-2923.2001.00726.x

Bayram, N., \&Bilgel, N. (2008). The prevalence and socio-demographic correlations of depression, anxiety and stress among a group of university students. Soc Psychiatry Psychiatr Epidemiol, 43, 667-672. https://doi.org/10.1007/s00127-008-0345-x

Bramness, J. A., Fixdal, T. C., \& Vaglum, P. (1991).Effect of medical school stress on the mental health of medical students in early and late clinical curriculum. Acta Psychiastr Scand, 84, 340-345. https://doi.org/10.1111/j.1600-0447.1991.tb03157.x

Chandavarkar, U., Azam, A., \&Mathews, C. A. (2007). Anxiety symptoms and perceived performance in medical students. Depress Anxiety, 24, 103-111. https://doi.org/10.1002/da.20185

Dahlin, M., Joneborg, N., \& Runeson, B. (2005). Stress and depression among medical students: a cross sectional study. Med Educ, 39, 594-604. https://doi.org/10.1111/j.1365-2929.2005.02176.x

Dyrbye, L. N., Thomas, M. R., \& Shanafelt, T. D. (2006). Systematic reviewof depression, anxiety, and other indicators of psychological distress among U.S. and Canadian medical students. Acad Med, 81, 354-373. https://doi.org/10.1097/00001888-200604000-00009

Hershner, S. D., \& Chervin, R. D. (2014). Causes and consequences of sleepiness among college students. Nature and Science of Sleep, 6, 73-84. https://doi.org/10.2147/NSS.S62907

Johari, A. B., \&Noor, H. I. (2009).Stress and coping strategies among medical students in National University of Malaysia, Malaysia University of Sabah and Universiti Kuala Lampur Royal College of Medicine Perak. Journal of Community Health, 15, 107-115.

Khosla, P., \& Chaudhuri, S. (March, 2017). The level of stress among nursing students in selected nursing college, Odisha, International Journal of Current Research, 9(3), 48018-48020.

Malathi, A., \& Damodaran, A. (1999). Stress due to exams in medical students-role of yoga. Indian J PhysiolPharmacol. $43,218-224$.

Naidoo, S. S., Van, W. J., Higgins-Opitz, S. B., \& Moodley, K. (2014). An evaluation of stress in medical students at a South African university. South African Family Practice, 56(5), 258-262. 
https://doi.org/10.1080/20786190.2014.980157

Niemi, P. M., \& Vainiomaki, P. T. (1999). Medical students' academic distress, coping and achievement strategies during the pre-clinical years. Teach Learn Med., 11, 125-134. https://doi.org/10.1207/S15328015TL110302

Sani, M., Mahfouz, M. S., Bani, I., Alsomily, A. H., \&Alagi, D. (2012). Alsomily NY. Prevalence of stress among medical students in Jizan University, Kingdom of Saudi Arabia. Gulf Medical Journal, 1(1), 19-25.

Shah, M., Hassan, S., Malik, S., \& Sreeramareddy, C. T. (2010). Perceived stress, sources and severity of stress among medical undergraduates in a Pakistani Medical School. BMC Med Educ., 10, 2. https://doi.org/10.1186/1472-6920-10-2

Shawaz, I., Sandhya, G., \& Venkatarao, E. (2015).Stress, anxiety \& depression among medical undergraduate students \& their socio-demographic correlates. Indian J Med Res, 141, 354-357. https://doi.org/10.4103/0971-5916.156571

Sherina, M. S., Lekhraj, R., \& Nadarajan, K.(2003).Prevalence of emotional disorders among medical students in a Malaysian university. Asia Pacific Family Medicine, 2, 213-217. https://doi.org/10.1111/j.1444-1683.2003.00089.x

Shriram, V., Bhimani, N., Aundhakar, N., Zingade, U., \& Kowale, A. (2015). Study of perceived stress among I MBBS medical students. JETHS, 2(1), 8-12

Singh, A., \&Lal, A. S. (2010).Prevalence of depression among 12.medical students of a private medical college in India. Online J Health Allied Sci., 9, 8.

Soumya, S., Richa, T., Rohit, K., \& Sarthak, S. Prevalence of anxiety and insomnia among medical students international Journal of Basic and Applied Medical Sciences, 5(2), May-August, 45-50

Supe, A. N. (1998). A study of stress in medical students at Seth G.S. 13.Medical College. J Postgrad Med., 44, 1-6.

Triin, E., Anu A., Vasar V., \& Veldi, M. (2006). Depression in Estonian medical students with sleep problems. Depress Anxiety, 23, 250-256. https://doi.org/10.1002/da.20166

\section{Copyrights}

Copyright for this article is retained by the author(s), with first publication rights granted to the journal.

This is an open-access article distributed under the terms and conditions of the Creative Commons Attribution license which permits unrestricted use, distribution, and reproduction in any medium, provided the original work is properly cited. 